\title{
The Influence of Human Value at Organizational Culture and Work Environment on Workforce Performance in Limited Companies
}

\author{
Magito $^{1}$, C. Catur Widayati ${ }^{2}$, Victoryza ${ }^{3}$ \\ \{catur.widayati@mercubuana.ac.id'1,magito@mercubuana.ac.id ${ }^{2}$, victoryza@gmail.com ${ }^{3}$ \} \\ Management Department, Faculty of Economy and Business, Universitas Mercu Buana, \\ Jakarta, Indonesia ${ }^{1}$, Management Department, Faculty of Economy and Business, \\ Universitas Mercu Buana, Jakarta, Indonesia ${ }^{2}$, Management Department, Faculty of \\ Economy and Business, Universitas Mercu Buana, Jakarta, Indonesia ${ }^{3}$
}

\begin{abstract}
The goal of this study is to examine the effect of human value creation on limited companies in the corporate culture and work environment. The research location was conducted in a limited company that produces building materials in Indonesia, namely PT Ficampindo Sentosa Jaya Bogor, Central Java. The research design used in this research is quantitative. The sample used was 30 respondents. The data analysis technique used the Structural Equation Model analysis tool using Smart-PLS. The results showed that the development of human value in company culture and work environment positively and significantly affected workforce performance at the company. The expected implication is that this research can be a reference for limited companies in strategic steps to improve employee performance. Developing human values and the company environment makes a good contribution to workforce psychology development and is expected to improve workforce performance in the future significantly.
\end{abstract}

Keywords: Human Value, Organizational Culture, Work Environment, Workforce Performance.

\section{Introduction}

The basic aspect of an organization's life is human resources. They have given their energy, talents, creativity, and efforts to the organization [1]. Therefore, the development of a company can be determined from human resources who are able to give the best performance. Human resource management must maintain the several of human behavior. Human resource problems become a challenge for management, because the success of the company depends on the quality of human resources. [2] stated that humans always play active role in determining plans, systems, processes, and goals to be achieved by the company. It is difficult to achieve company's goals without the participation from employees even though the company has the supporting facilities and infrastructure as well as funds. This shows that human resources are the key that must be considered with all their needs.

The meaning of organizational culture has the same perception among all organizational members [1]. [3] Defining organizational culture as an invisible force in a system with a popular meaning shared by a group/member organization. Furthermore, [4] stated that a system that has a common meaning as well as differentiates it from other organizations 
formed by its members. This is supported by the statement of [5], stated that company culture helps understanding the activities of the organization and employees in order to communicate more effectively and efficiently, improves cooperation with other employees because they teach each other the company's mentality directly.

Research conducted by Olu Oju notes that the relationship between organizational culture and company efficiency is positive. Human values are based on understanding the basic psychological needs, respecting others' contributions and peculiarities, and helping them reach their positive potential. This means that the human values that exist in organizational culture have an important role in the company [5]. While the work environment does not contribute directly to a company's manufacturing process, it has a significant effect on employee results [6]. The work environment can create a binding work relationship among the people within the environment. Therefore, management needs to make efforts to create good and conducive work environment that makes employees feel happy and excited in carrying out their respective duties.

According to [7], Work environment includes all of the things around the employee that can affect on doing work, for example, cleanliness, music, and others. Meanwhile, [8] stated that the type of work environment was divided into two, there are: (1) Climate for Physical Work and (2) Climate for non-physical jobs. Indicators of the work environment are: lighting, space for movement, and work relations.

A good work atmosphere and community of a company have an important role to play in enhancing the efficiency of the most efficient workers. Pursuant to Mohamad (2006) Performance is the level of accomplishment in achieving the organization's goals, priorities, purpose and vision found in a company's strategic planning for the execution of an operation or program or policy [9]. If it relates to performance as a noun, then the concept of performance is the job that a person or group of persons in an organization can do in compliance with their respective authorities and obligations in an attempt to legally achieve business objectives, does not break the law.

This research conducted in PT Ficampindo Sentosa Bogor. The role of the leader in maintaining the organizational culture on PT Ficampindo Sentosa Jaya classified as good. This is proven by the existence of good role models as leaders who have good work discipline. They are open to constructive criticism and suggestions. They always carry out regular scheduled and unscheduled evaluations of all activities in the company.

Based on physical environment prasurvey at PT Ficampindo Sentosa Jaya, this company was in the good category. This could be seen from the design which focused on giving the best supporting for employees. The lighting was good enough because of the office space used white lights and used air conditioning so that employees and distributors feel comfortable. Room design has also been arranged in such a way as to support service activities for employees.

Based on the description above, human values in the company's culture and physical environment are good enough, but there is still a significant decline in workforce performance during the last month in the operations division; this directly affects the company's development. This is the focus of this research. The research will explore the influence of human values on the culture and work environment of limited companies, precisely at PT Ficampindo Senotosa Jaya, which produces building materials to meet the community's needs.

\section{Literature Review}




\subsection{Organizational culture}

The effectiveness of the company depends on several factors. One of them is the human aspect. The development and deflation of company are also inseparable from this human aspect, so that it becomes the main concern of the management control system. In line with this view, McGregor with his theory X explained that in fact humans have a tendency to be lazy, less enthusiastic in trying or to implement job [10].

[11] stated that organizational culture needs to be differentiated into strong and weak cultures. A strong culture is shown by organizational values which are reflected in employee behavior. The greater the organizational values that can be accepted by employees, the stronger the organizational culture will be formed, so that the effect is more visible on employee behavior. A strong culture is formed because of the values and a strong leadership style. In addition, a strong culture is determined by togetherness and identity. [12] Stated that a strong organizational culture will trigger employees to think, act, and behave in accordance with organizational values. The suitability between organizational culture and organizational members support will lead to job satisfaction.

Therefore, a strong organizational culture is needed by every organization so that job satisfaction and employee performance will be increased so that it will improve overall organizational performance. Furthermore, [10] It claimed that the members establish a system of common meaning and also a differentiator from other organizations. According to Turner in [11] organizational culture is the behavioral, social, and moral norms that underlie every action in an organization and are shaped by the beliefs, attitudes and priorities of its members. It can be inferred from some of the above meanings that organizational culture is a framework of reciprocal agreement between beliefs, norms, and actions in an organization that is binding and distinguishes between one organization and another.

\section{Dimensions and Indicators of Organizational Culture}

According to Robbins (2008) There are seven main characteristics which are the essence of developing human value in organizational culture, including [10]:

a) Innovation and the taking of chances: (i) Opportunities for mutual cooperation; (ii)The opportunity to be creative; (iii) Willing to take responsibility for risks; (iv) The opportunities to innovate;

b) Attention to detail: (i) Be thorough at work; (ii) Respond if there are problems related to the office;

c) Result orientation: (i) The Freedom in determining how to work and express opinions;

d) Orientation of people: (i) Providing motivation in applying smiles, greetings, and discipline; (ii) Giving rewards for encouraging existing cultures;

e) Team orientation: (i) A closer relationship with other colleagues;

f) Aggressiveness: (i) The urge to be competitive; and

g) Stability: (i) Work according to work procedures.

\subsection{Work environment}

The work environment is a very important component when employees carry out work activities. By paying attention to a good work environment or creating working conditions that are able to provide motivation to work, it will have an effect on employee enthusiasm at work. Pursuant to Oyserman, Bybee, and Terry (2006), work environment can be defined as the forces that influence, either directly or indirectly, on the performance of an organization or company [13]. 
Work environment is all around the employees and can affect them in carrying out their jobs, for example cleaning, music, lighting, and others. According to, the definition of the work environment is the entire tool and material, the surrounding environment of works, work methods, and work arrangements both as individuals and as a group[14] .

Work environment is defined as a condition related to the characteristics of the workplace towards employee behavior and attitudes. Based on the above definition, the scope of the work environment is: (1) organizational environment is reflected in employees. The leadership style adopted by democratic leaders will also affect employees; (2) work environment that arises in the organization is a factor that determines employee behavior [15].

\subsection{Work Environment Indicators}

According to [14], work environment can be measured by the following indicators: (1) Temperature of the room; (2) Air circulation in the workplace; (3) Lighting in the workplace; (4) level noise sound at work; (5) work facilities; (6) Employee relations; (7) work regulations; and (8) sense of security.

\subsection{Workforce performance}

It is said that the real meaning of success is the achievement or performance of both individuals and groups, both quality and quantity obtained from the unity of time span that comes from human resources. Those who carry out their job duties are by their responsibilities by the company or organization [16].

Output is the job outcome for the obligation of the tasks, both quality and quantity accomplished by an employee. Performance is the outcome that an individual or community in an organization should accomplish in compliance with their respective duties in order to lawfully achieve organizational objectives, not break the law, and in accordance with ethics. Performance is sometimes defined as the accomplishment of a task based on the thinking of the tasks needed by employees, since employee performance is an action taken by employees to perform the company's work [17].

Employee performance is everything that affects the contribution to the organization. In an organization, success is very necessary in order to achieve its objectives. Performance can run well if employees get a salary according to expectations, get training and development, good work environment, receive the same treatment, strengthen employees according to their expertise and get career planning assistance, and there is feedback from the company [18].

The dimensions and performance indicators of the workforce are as follows: (1) Quality of work of individuals; (2) Honest attitude of the workforce; (3) Initiatives undertaken in carrying out work; (4) Attendance of employees; (5) Attitudes with the company environment; (6) Cooperation; (7) Justice; (8) Knowledge of work; (9) Responsibility for the company and the work environment; (10) Utilization of working time [16].

The framework of thinking from independent variables Human Value in Organizational Culture $\left(\mathrm{X}_{1}\right)$ and Limited company Work Environment $\left(\mathrm{X}_{2}\right)$ and dependent variable employee performance $\left(\mathrm{Y}_{1}\right)$ as follow: 


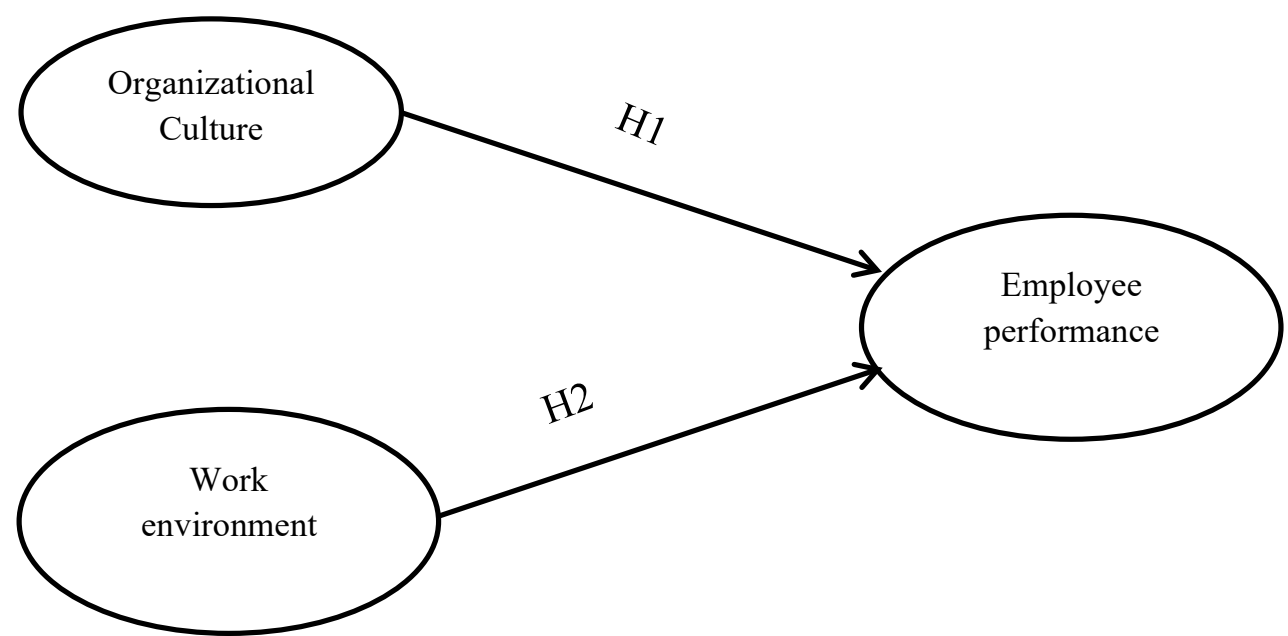

Figure 1. Research Conceptual Framework Model

Hypothesis

H1: Human Value in Organizational culture has a positif and significant effect on workforce performance

H2: The work environment has a positive and significant effect on workforce performance

\section{Methods}

Researchers determined that the population was 30 employees of PT Ficampindo Sentosa Jaya. Based on the total population at PT Ficampindo Sentosa Jaya, the sample used is 30 workforces. The sampling technique in this research used saturated sampling technique.

The system of data analysis used the Portion or Variance Based Structural Equation Model where the Partial Least Square (Smart-PLS) version 3.0 PLS program was used for data processing. An alternative model of covariance based SEM is PLS (Partial Least Square). PLS may be used to verify the hypothesis, as well as to clarify whether or not there is a correlation between latent variables. PLS (Partial Least Square) is a powerful method of analysis since it does not rely on several assumptions, it does not have to allocate data normally, and the sample does not have to be large [19].

\section{Results and Discussion}

\subsection{The Results of Data Quality Test}

The Convergent Validity Test Result The measurement model with reflexive indicators is evaluated on the basis of the correlation between the item score or part score and the PLS 
measured build score. Individual measures, whether they have a correlation value above 0.70 , are considered accurate. The loading factor of 0.50 to 0.60 is still appropriate in scale development study, however. It was found from the results of the convergent validity test that all indicators were said to be accurate since all indicators met the convergent validity value with a loading factor value above 0.60 .

\section{a. The Result of Discriminant Validity Test}

A reflective indicator that can be seen in the cross loading between the indicator and the build is the product of the Discriminant Validity Test. If it has the highest loading factor for the intended construct compared to the loading factor for other constructs, an indicator may be considered true. Thus, latent constructs predict indicators in their block better than indicators in other blocks.

It can be shown that the correlation of organizational culture constructs with their indicators $(\mathrm{BO} 1$ is $0.881, \mathrm{BO} 2$ is $0.667, \mathrm{BO} 5$ is $0.759, \mathrm{BO} 6$ is $0.859, \mathrm{BO} 7$ is $0.886, \mathrm{BO} 8$ is 0.868 , and $\mathrm{BO} 9$ is 0.899 ) is higher than the correlation of organizational culture indicators in the results of discriminant validity research. Then, with other structures, the connection between the construction of the work environment and the indicators (LK2 is 0.690, LK3 is 0.811 , LK4 is 0.766 , LK5 is 0.832 , LK6 is 0.864 , and LK8 is 0.864 ). The correlation between employee performance constructs and indicators (KK1 is $0.806, \mathrm{KK} 2$ is 0.789 , KK 3 is 0.782 , KK5 is $0.788, \mathrm{KK} 6$ is 0.852 , KK 7 is 0.836 , and $\mathrm{KK} 8$ is 0.858 ) is greater than the correlation between employee performance indicators and other constructs.

Knowing discriminant validity is the value of each construct from the square root of average variance derived (AVE) with the correlation between constructs and other constructs in the model, so it can be assumed that it has strong discriminant validity.

Table 1. AVE Test Results

\begin{tabular}{lc}
\hline \multicolumn{1}{c}{ Variable } & AVE \\
Human value on companies culture & 0.697 \\
Work environment & 0.651 \\
workforce performance & 0.666 \\
\hline
\end{tabular}

Source: PLS output

Table 2. Discriminant Validity Performance Test (Fornell Lacker Criterium)

\begin{tabular}{lccc}
\hline & $\begin{array}{c}\text { Organizational } \\
\text { culture }\end{array}$ & $\begin{array}{c}\text { workforce } \\
\text { performance }\end{array}$ & $\begin{array}{c}\text { Work } \\
\text { environment }\end{array}$ \\
\hline $\begin{array}{l}\text { Human value on } \\
\text { companies culture }\end{array}$ & $\mathbf{0 . 8 3 5}$ & & \\
$\begin{array}{l}\text { workforce } \\
\text { performance }\end{array}$ & 0.758 & $\mathbf{0 8 1 6}$ & \\
Work environment & 0.566 & 0.733 & $\mathbf{0 . 8 0 7}$ \\
\hline
\end{tabular}

Source: PLS output

It can be inferred from Tables 1 and 2 that the square root of the average variance is derived from $(\sqrt{A V E})$ The association between one construct and the other constructs in the model is greater than for one construct. The AVE value is based on the above table and it can 
be inferred that the constructs follow the requirements for discriminant validity in the estimated model.

\section{b. Composite Reliability and Alpha Test Performance of Cronbach}

In a research model, evaluating composite durability and Cronbach's alpha aims to assess the reliability of the methods. If all latent variables have a composite reliability value or Cronbach's alpha 0.7 , it indicates that the construct has good reliability or has been reliable or compatible with the questionnaire used as a guide in this analysis.

Table 3. Composite Test Reliability Results

\begin{tabular}{lccc}
\hline variables & $\begin{array}{c}\text { Composite } \\
\text { Reliability-test }\end{array}$ & reliable \\
\cline { 1 - 1 } Human value on companies culture & 0,941 & $\sqrt{ }$ \\
Work environment & 0,933 & $\sqrt{ }$ \\
workforce performance & 0,918 & $\sqrt{ }$ \\
\hline
\end{tabular}

Source: PLS output, 2020

Table 4. Cronbach's Alpha Test Results

\begin{tabular}{lcc}
\hline \multicolumn{1}{c}{ variables } & $\begin{array}{c}\text { Cronbach's } \\
\text { Alpha-test }\end{array}$ & reliable \\
\hline Human value on companies culture & 0,926 & $\sqrt{ }$ \\
Work environment & 0,916 & $\sqrt{ }$ \\
workforce performance & 0,892 & $\sqrt{ }$ \\
\hline
\end{tabular}

Source: PLS output, 2020

The test results for composite reliability and Cronbach's alpha indicate a satisfactory value based on Tables 3 and 4, since all latent variables have a composite reliability value and Cronbach's alpha is 0.70 . This implies that all latent factors are reliable.

\subsection{Testing Structural Model or Testing Hypothesis}

The development of a definition and theory-based model to examine the relationship between exogenous and endogenous variables defined in a conceptual context is the inner model test. The test steps for the structural model are as follows (inner model):

a. Results of Testing the $\mathbf{R}_{\text {square }}$ Value

The result of $\mathrm{R}_{\text {square }}$ value as follow:

Table 5. Value $\mathbf{R}^{2}$ Endogenous Variables 


\begin{tabular}{cc}
\hline $\begin{array}{c}\text { Endogenous } \\
\text { Variables }\end{array}$ & R square \\
\hline workforce performance & 0,711 \\
\hline Source PLS
\end{tabular}

Source: PLS output, 2020

The structural model indicates that, since it has a value above 0.67 , the model on the workforce performance variable is solid. The model of the effect on workforce efficiency of independent latent variables $\left(\mathrm{X}_{1_{-}}\right.$Human value in companies culture and $\mathrm{X}_{2}$ workforce performance) provides R-square value 0.711 which can be translated as 71.1 percent of the variability of the Employee Performance construct that can be explained by the variability of the constructs of the Organizational Culture and Work Environment while 28.9 percent is explained by 0 .

\section{b. Goodness of test results for Suit Model}

The outcome of the structural model of Goodness of Fit on the inner model using the importance of predictive relevance $\left(Q^{2}\right)$. The Qsquare value is greater than 0 (zero), suggesting a predictive significance value for the model.

The results of the calculations above show that the value of predictive significance is 0.711 , which is greater than 0 (zero). This suggests that the independent variable used describes 71.1 per cent of the variance in workforce output variables. The model thus has the required predictive value.

\section{b. The result of Hypothesis test}

The estimated values in the structural model for the path relationships must be important. The value of this hypothesis can be obtained by the boostrapping process. You can see the importance of the hypothesis from the coefficient value of the parameter and the $T_{\text {statistical }}$ significance value of the boostrapping study algorithm. It can be seen from the $T_{\text {table }}$ at alpha 0.05 ( 5 percent $)=1.96$ to determine whether or not it is important, then the $T_{\text {table }}$ is compared with the $\mathrm{T}_{\text {count }}\left(\mathrm{T}_{\text {statistic }}\right)$.

Table 6. Testing Outcomes Hypothesis

\begin{tabular}{lcccc}
\hline & $\begin{array}{c}\text { Original } \\
\text { Sample }\end{array}$ & $\begin{array}{c}\text { Standard } \\
\text { Deviation }\end{array}$ & $\begin{array}{c}\text { T- } \\
\text { Statistics }\end{array}$ & Information \\
\hline $\begin{array}{l}\text { Human value on } \\
\text { companies culture -> } \\
\text { workforce }\end{array}$ & 0.505 & 0.127 & 3,976 & Positive - Significant \\
$\begin{array}{l}\text { Performance } \\
\begin{array}{l}\text { Work Environment -> } \\
\text { workforce } \\
\text { Performance }\end{array}\end{array}$ & 0.447 & 0.142 & 3,144 & Positive- Significant \\
\hline
\end{tabular}

Source: PLS output, 2020 


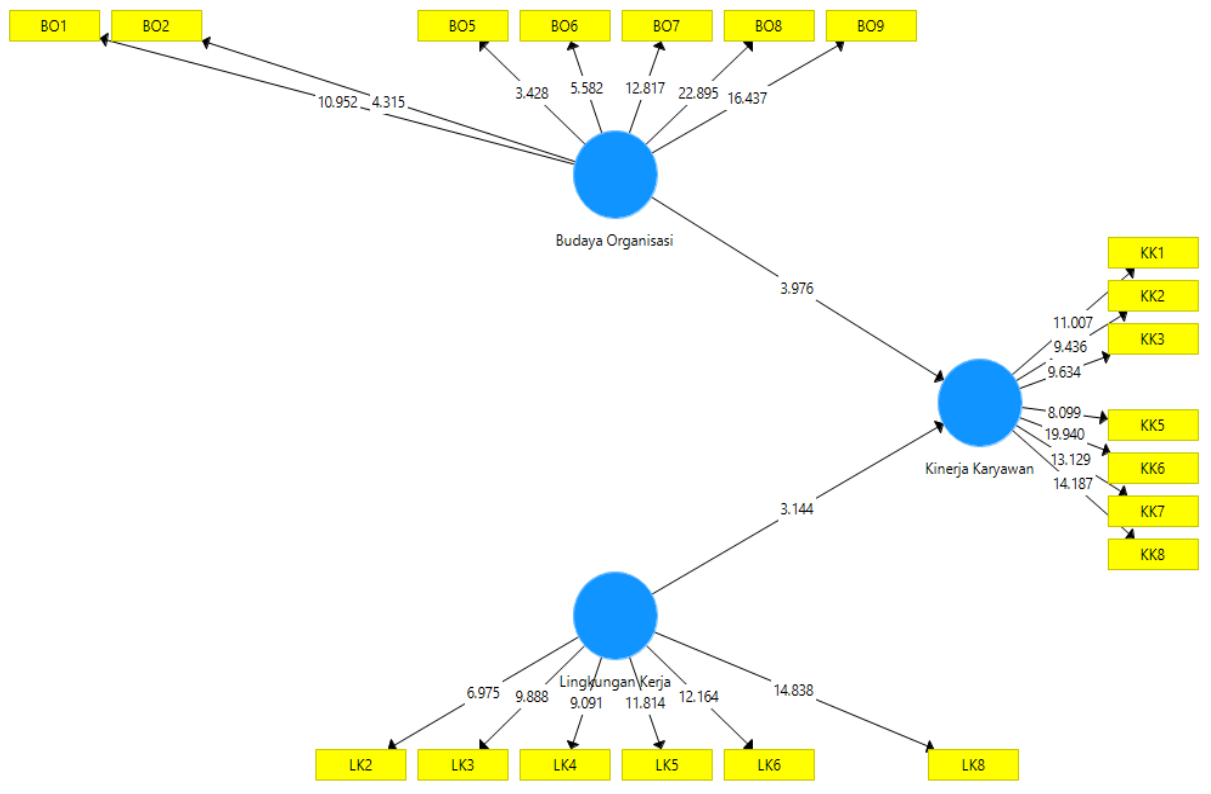

Figure 2. Boostrapping Test Results Source: PLS output, 2020

1) The Effect of Human value on Organizational Culture on workforce Performance

The $\mathrm{T}_{\text {statistic }}$ value is 3,976 based on the results of the hypothesis test, and the initial sample value is 0,505 . $T_{\text {statistic }}$ value is greater than the $T_{\text {table }}$ value of 1,96 and positive value is demonstrated by the original sample value, these findings indicate that human value on organizational culture has a positive and important impact on the output of employees. Previous research has confirmed the findings of this hypothesis that organizational culture has a positive and important influence on the success of the workforce. [20], [21], [22], [23]. This is because the corporate culture generated in the business is enforced by the leaders and owners and can promote the behavior and transparency of the employees so that the goals of the company can be accomplished.

\section{2) The Effect of Work Environment on workforce Performance}

The $\mathrm{T}_{\text {statistic }}$ value is 3,144 based on the results of the hypothesis test, and the initial sample value is 0.447 . $T_{\text {statistic }}$ value is greater than $T_{\text {table }}$ value 1.96 and positive value is demonstrated by the original sample value, which indicates that the work environment has a positive and important influence on the output of the workers. Previous research has reinforced the outcome of the hypothesis that the work environment has a positive and important impact on employee efficiency. [24], [22], [25]. This happens because the comfortable condition and facilities owned by the company support the work of workforce so that workforce are able to carry out their job responsibilities with enthusiasm and optimal. 


\section{Conclusion and Suggestion}

Human values on organizational culture have a positive and significant effect in the workforce performance of PT Ficampindo Sentosa Jaya. This means that a high human value in corporate culture, especially what leaders do to their subordinates, will increase workforce performance. In contrast, the low human value in corporate culture will reduce workforce performance. Work environment has positive and significant effect on workforce performance of PT Ficampindo Sentosa Jaya. This means that good work environment will increase workforce performance; on the other hand, bad work environment will reduce workforce performance.

Suggestions for PT Ficampindo Sentosa Jaya so that management continues to create and increase the role of human values in the organizational culture and work environment built within the company so that workers can feel comfortable carrying out their work, this will make the company's goals achieved optimally. For further research, it is better to develop variables and indicators that have not been used in this study. Further researchers can use variables of job satisfaction, job stress, leadership style, organizational commitment, and so on.

\section{References}

[1] S. PS, Manajemen Sumber Daya Manusia. Bumi Aksara, Jakarta, 2008.

[2] T. C. C. Jackson, F. M., Rowley, D. L., \& Owens, "Contextualize, women," Women's Heal. Issues, vol. 22, no. 3, pp. 329-336, 2012.

[3] Gudono, Analisis Data Multivariate, 2nd ed. BPFE, Yogyakarta, 2012.

[4] S. Notoatmodjo, Pengembangan Sumber Daya Manusia. Rineka Cipta, Jakarta, 2009.

[5] O. Ojo, "Organisational Culture And Corporate Performance: Empirical Evidence From Nigeria," J. Bus. Syst. Gov. Ethics, vol. 5, no. 2, pp. 1-12, 2010.

[6] B. Andreas, Organisasi: Menuju Pencapaian Kinerja Optimum. Prasetya Mulya Publishing, Jakarta, 2011.

[7] A. Nurhasanah, "Kerja Karyawan Pada Bank Indonesia Cabang Samarinda," vol. 6, no. 1, pp. 1349-1356, 2010

[8] Sedarmayanti, Manajemen Sumber Daya Manusia. Refika Aditama, Bandung, 2011.

[9] M. Mohamad, No Title. Yogyakarta: BPFE Yogyakarta, 2006.

[10] dan J. Robbins SP, Perilaku Organisasi, Buku 2. Jakarta: Salemba Empat, 2008.

[11] S. J. Luthans, F., Avey, J. B., Avolio, B. J., \& Peterson, "No Title," Hum. Resour. Dev. Q., vol. 21, no. 1, pp. 41-67, 2010.

[12] D. Sulistiawan, S. S. Riadi, and S. Maria, "Pengaruh budaya organisasi dan lingkungan kerja terhadap kinerja pegawai," Kinerja, vol. 14, no. 2, p. 61, 2018, doi: 10.29264/jkin.v14i2.2480.

[13] K. Oyserman, D., Bybee, D., \& Terry, "Possible selves and academic outcomes: How and when possible selves impel action,” J. Pers. Soc. Psychol., vol. 91, no. 1, p. 188, 2006.

[14] D. Sunyoto, Penelitian Sumber Daya Manusia. Cetakan Pertama CAPS: Jakarta, 2015.

[15] M. Ravasi, D., \& Schultz, "Responding to organizational identity threats: Exploring the role of organizational culture," Acad. Manag. J., vol. 49, no. 3, pp. 433-458, 2006, doi: https://doi.org/10.5465/amj.2006.21794663.

[16] A. A. A. P. Mangkunegara, Manajemen Sumber Daya Manusia Perusahaan. Bandung: PT Ramaja Rosdakarya, 2011.

[17] L. Demet, "Impact Of Workplace Quality On Employee's Productivity: Case Study Of a Bank in Turkey PhD Candidate, Okan University, Turkey," J. Business, Econ. Financ., vol. 1, no. 1, pp. 38-49, 2012. 
[18] A. Goncharuk, "Measuring Enterprise Performance to Achieve Managerial Goals," J. Appl. Manag. Investments, vol. 3, no. 1, pp. 8-14, 2014, doi: January 2014.

[19] Ghozali, Imam, No Title. 2015.

[20] U. Memperoleh, G. Sarjana, and G. B. Kharisma, Pengaruh budaya organisasi dan lingkungan kerja terhadap kinerja karyawan koperasi serba usaha setya usaha di kabupaten jepara. 2013.

[21] R. Kusumawati, "Analisis Pengaruh Budaya Organisasi Dan Gaya Kepemimpinan Terhadap Kepuasan Kerja Untuk Meningkatkan Kinerja Karyawan (Studi Kasus Pada RS Roemani Semarang) (Doctoral dissertation, Program Pasca Sarjana Universitas Diponegoro)," 2008.

[22] H. T. Susetyo, W.E., Amiartuti Kusmaningtyas, "Pengaruh Budaya Organisasi Dan Lingkungan Kerja Terhadap Kepuasan Kerja Dan Kinerja Karyawan Pada PT. Bank Muamalat Indonesia Divisi Konsumer Area Cabang Surabaya," JMM17 J. Ilmu Ekon. Manaj., vol. 1, no. 1, pp. 8393, 2014.

[23] N. Arianty, "Pengaruh budaya organisasi terhadap kinerja pegawai," J. Ilm. Manaj. dan Bisnis, vol. 14 , no. 2,2015

[24] N. . Rahmawanti, "Pengaruh Lingkungan Kerja Terhadap Kinerja Karyawan (Studi pada Karyawan Kantor Pelayanan Pajak Pratama Malang Utara).,” J. Adm. Bisnis, vol. 8, no. 2, 2014.

[25] Hidayat, Z., \& Taufiq, M, "No Title," J. Penelit. Ilmu Ekon., vol. 2, no. 1, pp. 36-64, 2012. 